\title{
TRENDS AND PATTERNS IN
}

\section{NUTRITIONAL INTAKE IN INDIA}

\author{
Jignesh Shah \\ Ayush Kumar \\ and \\ TNDatta*
}

\begin{abstract}
According to Nutritional Intake Survey Series, conducted by the National Sample Survey Organisation (NSSO), there has been slow, but steady decline in consumption of calories and proteins, but the consumption of fat has been increasing both in rural and urban India. Unlike calorie and protein, the difference in fat intake between rural and urban areas is pronounced. In the country, the States belonging to north eastern region seem to be lagging in terms of nutritional intake when compared to the national average. Among calorie, protein and fat, it is the protein where relatively lesser number of States in the country have exhibited positive trend during 2004-05 and 2011-12. In terms of calorie intake, about 39 percent of country's population remains undernourished. However, there has been a decrease of about 33 million people who registered to have deficient intake of calories during 2004-05 and 201112. With rise in food expenditure among rural and urban masses, there has been less than proportionate increase in calorie, protein and fat intake. Yet, relatively higher propensity has been witnessed to consume more of fat with the rise in food expenditure.
\end{abstract}

\section{Introduction}

Even after witnessing substantial progress in most of our endeavours like technology, art, science, defence, industrialisation, etc., ironically the most basic needs of vast majority population of the country are yet to be fulfilled,i.e.,availability and affordability of a nutritious and healthy meal.India's economy has grown rapidly, especially since 1990s and has been evolving constantly, particularly in relation to the inclusiveness of this growth process. In the post-economic reforms period, India not only experienced rapid economic transformation

*Senior Manager, Deputy Manager and General Manager, respectively, National Dairy Development Board, Anand, Gujarat, India.

Journal of Rural Development, Vol. 36, No. 3, July-September : 2017 
but also substantial changes in many other dimensions of well-being, including in its diet pattern (Ali, 2007; Atibudhi, 2006; Giri, 2006;Golait and Pradhan, 2006; Naseerudeen et al. 2006; Singh et al.2006; Viswanathan, 2001; Shariff and Mallick, 1999 and Radhakrishna and Reddy, 2004).

According to World Bank Report (2011),"South Asia still has the highest rates and the largest number of undernourished children in the world," and also "the high economic growth experienced by South Asian countries has not made an impact on the nutritional status of South Asian children."

Nevertheless, there has been an improvement in most of the indicators over the past few decades. Though the progress has been sluggish and the desired levels are yet to be achieved, yet there is a marked improvement in the quantity of food being consumed, not necessarily the quality. This highlights some of the insights from various reports published by the NSS under the series, "Nutritional Intake in India."The report mainly focuses on the quantity of energy measured in kilo calories (Kcal) being consumed, nutrients like protein, fat and their sources among various socio-economic classes for the country as a whole and also at the State level.

Given the vast geographical spread, altering topography and rich history, one thing that the country has inherited is "diversity" which is ubiquitous in our nation, be it anything, like the culture, taboos, tradition, lifestyle, ... and the "diet" is no exception. Through this paper, it is intended to highlight this diversity in the diets and more importantly how far we are from the required diet or in other words how close are we to malnutrition. It is important to understand the true meaning of malnutrition here, which is commonly used interchangeably with the term undernutrition. But, unlike undernutrition, malnutrition means improper diet; it can be both ways either excess or deficiency of different nutrients.

The International Conference on Nutrition (ICN, 1992) described six important determinants of malnutrition, which need to be involved in nutrition strategies. They are (i) Production, mainly agricultural and food production, (ii) Preservation of food from wastage and loss, which includes the addition of economic value to food through processing, (iii) Population, which refers both to child spacing in a family and also to population density in a local area or a country, (iv) Poverty, which suggests economic causes of malnutrition, (v) Politics, as political ideology, political choices and political actions influence nutrition and (vi) Pathology, which is the medical term for disease, since disease, especially infection, adversely influences nutritional status.

\section{Objective}

Based on the secondary data, the major objective is to highlight the trend as well as cross-sectional comparisons in terms of calorie, fat and protein intakes among Indians both in urban and rural regions. 
Here, using the RDA or the recommended dietary allowances prescribed by the National Institute of Nutrition, Hyderabad, it is intended to analyse the prevailing levels of deficiency, sufficiency or superfluity in the intake of calories, proteins and fats in the country both in rural and urban areas. Alongside, it has also been attempted to look at the propensity of the people to consume across three types of intakes, viz., calorie, fat and protein in different regions of the country.

\section{Methodology}

The National Sample Survey Organisation releases series on Nutritional Intake in India on quinquennial basis. The State-wise data for the years 2004-05 and 2011-12 have been used for present analysis. However, wherever required, the data for previous rounds were also referred for better understanding and analysis. Apart from data, it is equally important to understand the theoretical background and basic concepts associated with nutrition. The same has been referred from National Institute of Nutrition and is explained below.

Energy: Everything what we consume is broken down by our digestive system and converted into energy. This energy is measured in terms of Kilo calories or Calories (represented as Kcal). 1 calorie is defined as the amount of heat required to raise the temperature of 1 gram of pure water by 1 centigrade (this is also equivalent to 4.19 joules). This energy is required to carry out various internal functions of human body and also physical activities that are done on daily basis.

Table 1: Recommended Dietary Allowances (RDA) for a 'Standard' Indian

\begin{tabular}{|c|c|c|}
\hline Energy/Nutrients & Unit & Value \\
\hline Calorie & Kcal/day & 2700 \\
\hline Protein & g/day & 60 \\
\hline Fat* & g/day & $60-90$ \\
\hline
\end{tabular}

That's why even a resting body needs some amount of energy which is popularly known as BMR (Basal Metabolic Rate). The excess energy is stored as fat and glycogen which are utilised when the body's needs are not fulfilled by the intake.

Nutrients: Mainly two types of nutrients are there namely, macronutrients and micronutrients. Macronutrients include carbohydrates, proteins and fats which are required in larger quantities and are structural and energy-giving caloric components. Micronutrients are the vitamins, minerals, trace elements, phytochemicals and antioxidants that are required in very minute quantities but are essential for good health and proper functioning of vital systems in the body. In this paper we will primarily focus on two of the macronutrients namely, protein and fat.

Proteins: Proteins are known as the building blocks of life. They are large biological molecules consisting of one or more chains of 
20 different amino acids. They are present in each human cell and most of the body fluids. Proteins are required to make new cells and repair and maintain body cells. Breakdown of one gram of protein releases four calories.

Major sources of protein include pulses, soyabeans, legumes, nuts, grains like wheat, meat, fish, eggs, milk, etc. The recommended daily intake of protein for normal Indian adult is $1 \mathrm{~g}$ per $\mathrm{kg}$ of body weight. Therefore, a 60 $\mathrm{kg}$ adult requires about $60 \mathrm{~g}$ of proteins every day.

Fats: They belong to a larger category called lipids and are made up of three kinds of fatty acid (FA) chain, i.e., saturated (SFA), monosaturated (MUFA) and poly-unsaturated (PUFA). These perform many structural and metabolic functions. The subcutaneous fat acts as an insulator and cushion. It aids in absorbing fat soluble vitamins. Fats are major source of energy during stress and breakdown of 1 gram of fat produces 9 calories. Thus, it is a concentrated source of energy and per unit weight it generates more than twice the energy released by carbohydrates and proteins.

Among health conscious people, mere mention of the word "fat" evokes a cold shudder in them. Unfortunately, fat remains one of the most misunderstood components of our diets.

Fats are vital for many metabolic functions, especially in children where it plays an important role in development of neurological systems and also overall growth of the body. Basically, fats can be broadly classified into two categories, viz., monounsaturated and polyunsaturated fats or the "good fats" and saturated or the "bad fats".

Dietary fats can be derived in the form of visible fats such as vegetable oils, vanaspati, ghee, butter and invisible fats which are present as an integral component of various foods. Food from animal sources and processed foods are rich in invisible fats. The small amounts of invisible fats add up to a significant level in our daily diet - about $15 \mathrm{~g}$ in rural population and $30 \mathrm{~g}$ among urban middle and high income groups (NIN, 2011).

The recommended total fat (visible+ invisible) intake should be around 20-30 per cent of the total calories. Therefore, for a healthy Indian adult of $60 \mathrm{~kg}$ body weight it works out to be 60-90 grams of fat every day. More importantly, assiduous effort is needed to make this information reach the public at large and also encourage them to adopt healthy diets.

In addition to the concepts above, some of the definitions, as available in NSS, used for analysis in the present research, are given below.

\section{Per Capita vs Consumer Unit}

The NSS report released by the government contains data in two units, viz., per capita and per consumer unit. In this paper, the consumer unit data has been used, the reason being a more appropriate 
representation of the dietary intake. One consumer unit,as defined by NSS, is a normative rate of equivalence of a given age-sex specific person in relation to a 'standard' male person doing sedentary work in the age group of 20 39. All other age and sex are adjusted according to the consumer unit. This gives a truer representation because the needs of the individual in terms of calories vary greatly with his/her age, sex, height, weight and activity level. All this is not taken into account when one computes in terms of per capita in which each individual is treated as the same one unit.

\section{MPCE Classes}

For any number ' $p$ ' between 0 and 100 , the MPCE level such that ' $p$ ' per cent of the population lies below it is called the pth percentile of the MPCE distribution (over persons). For any fraction ' $f$ ' between 0 and 1 , the MPCE level such that $100 \mathrm{f}$ per cent of the population lies below it is called the fth fractile of the MPCE distribution. Fractile classes are often referred to by the end points in percentile form. Thus, "0-5 per cent" refers to the bottom 5 per cent of population ranked by MPCE, "5-10 per cent" to the next 5 per cent of population ranked by MPCE, and so on. The fractile classes for which estimates are provided here (at all India rural/urban level only, not at State/UT level) are: 0-5 per cent, 5-10 per cent, 10-20 per cent, 20-30 per cent, 30-40 per cent, ..., 70-80 per cent, 80-90 per cent, 90-95 per cent, and 95-100 per cent. In the Tables, the above fractile classes have sometimes been referred to as $01,02,03, \ldots$,
11,12 , respectively and sometimes as $0-5,5-$ 10, 10-20, etc.

The country was divided into six different regions for understanding the regionwise trends. The six regions are North, East, West, South, North East and Union Territories.

Generally, ratio, percentage and averages are used to perform different analyses in present research. However, for calculating the propensity to consume calorie, fat or protein with rise in consumer expenditure, coefficients of elasticity were computed.

\section{Results and Discussion}

Trend in Consumption Pattern: The growing literature on the subject presents divergent views which can be organised into two broad categories. First category indicates that poverty and lack of purchasing power are believed to be the two major factors responsible for the low dietary intake and chronic undernutrition. It may be a result of neoliberal policies incepted since the early 1990s. Many researchers suggesting their views within this broad category are, among others, Mehta and Venkatraman (2000), Chandrasekhar and Ghosh (2003) and Patnaik (2004, 2007, 2010a,b) with slight variations. According to Utsa Patnaik, the most prominent proponent of this strand of research, the "puzzle" does not exist, because the explanation for lower calorie intake is lower real incomes.

The second category does not believe in this coercive factor, mostly researchers in 
this category argue that people consume lesser calories and nutrients because they willingly want to do so. Factors in this category include growth in real incomes explaining the declining share of food expenditure, diversification of diets, market integration and development of supply networks, urbanisation, changes in occupational structures, and mechanisation of agricultural work. Most of these factors hint towards decline in calorie needs and in turn to reduction in calorie intake. Among others, researchers like Rao (2000), Mittal (2007), Deaton and Dreze (2009) and Li and Eli (2010) fall in this category.

India defined poverty line on the basis of energy intake of the population and initiated interventions aimed at improving the purchasing power, access to subsidised food and essential goods and services to people below poverty line. The government has undertaken various development schemes like Mahatma Gandhi National Rural Employment Guarantee Scheme (MGNREGS), Food Security Act, etc., to address this concern. NSS consumer expenditure data on energy intake of urban and rural areas on inter-temporal basis provides useful platform for assessing the impact of these interventions on energy intake.

The observed trend in consumption over the years is worth mentioning. Basu\&Basole (2012) have observed that average calorie intake has declined over time in India even as real consumption expenditures (and by most measures real per capita incomes) have increased. Since cross-sectional evidence shows a robust positive relationship between per capita income and calorie intake, the time series pattern in India clearly present a puzzle. Moreover, the puzzle has been around for a long time. Since 1993-94, there has been slow, but steady decline in the consumption of calories in rural areas. It has reduced from $2683 \mathrm{Kcal} /$ consumer unit/day in 1993-94 to $2589 \mathrm{Kcal} /$ consumer unit/day in 2011-12. Similarly, in urban areas too, it has marginally declined from 2542 to $2519 \mathrm{Kcal} /$ consumer unit/day. Ray \& Lancaster (2005) and Ray (2007) also noticed strong evidence of a decline in per capita calorie consumption in India over the last 20 years; which has resulted in an increase in the rate of undernourishment.

The declining trend can also be observed in case of protein both in rural as well as in urban areas where it has decreased from 75.0 to $69.7 \mathrm{grams} /$ consumer unit/day and 70.2 to 68.1 grams/consumer unit/day in rural and urban areas, respectively, over the same time period (Figure 1). Interestingly, the absolute levels of calorie and protein intake per consumer unit are higher in rural areas, as compared to urban areas. In terms of fat consumption, it shows a trend contrary to the calorie and protein over years. The increase has been from 39.1 to $51.4 \mathrm{gram} /$ consumer unit/ day and 51.6 to $64.2 \mathrm{gram} /$ consumer unit/day in the rural and urban areas, respectively, in a span of 18 years ending 2011-12. It may be noteworthy that unlike calorie and protein, the fat consumption has been higher in urban areas and the gap in fat intake between rural and urban is also wider than that of calorie and protein. 
Figure1: Consumption of Daily Energy and Nutrients Per Consumer Unit (All India)

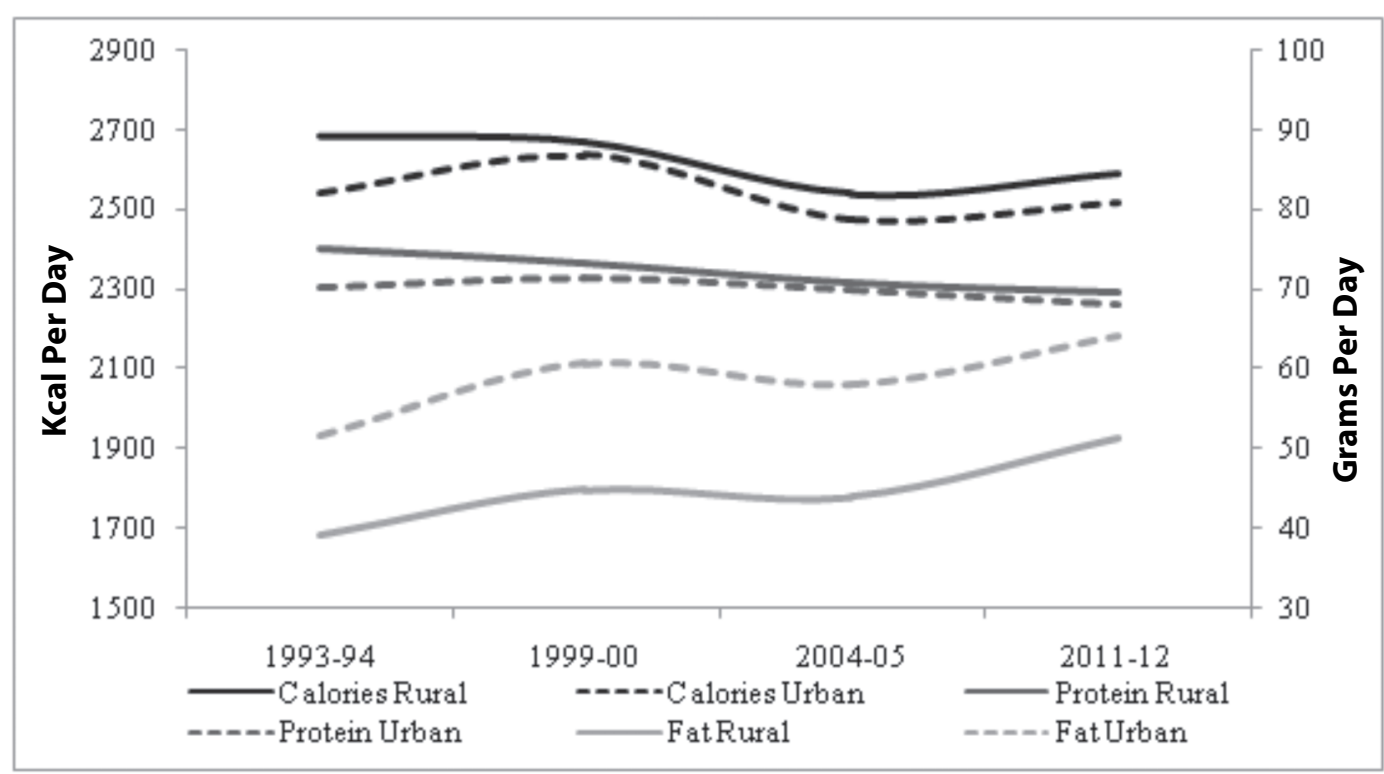

Some researchers argued that lower levels of energy intake are neither due to poor access to food as food supply has been adequate, nor due to economic constraints because food in general and cereal prices in particular have been low. The decline in energy intake might be due to reduction in energy expenditure attributable to the changes in lifestyle and reduction in physical activity (Ramachandran, 2008). The reduction in physical activity and therefore, optimum energy requirement may be the crucial factor in the on-going nutritional transition in India. Similar observations have also been made by Rao (2000), Mittal (2007), Deaton and Dreze (2009) and $\mathrm{Li}$ and Eli (2010). They indicated that people consume fewer calories because their calorie needs have declined over time due to improvement in the epidemiological environment, changes in occupational structures and mechanisation of agricultural work. While they do not offer any direct evidence in support of the hypothesis, they do indicate that anthropometric measures such as height-for-age, weight-for-height, and weight-for-age among children and adult body mass index (BMI) have shown improvement over time in India. Under such views and counter-views, it is really a puzzle whether declining calorie levels are really a matter of concern. It may also be noted that the requirements of energy and nutrients have a time dimension too, which means under given socio-economic conditions in a particular period, the validity of the same was established. Given changes over years in living style and improvement in standard of living, such parameters cannot be accepted in perpetuity and calls for a reassessment. 
Improving dietary knowledge has the potential to prevent obesity and overweight (Shimokawa,2012).There is no doubt that fat is also required for the body, however, beyond a level, the fat content in the body is counterproductive. As far as increasing trend in fat intake is concerned, this needs to be arrested by spreading awareness through suitable means about implications of malnutrition (obesity) and other undesirable health complications due to higher levels of fat intake, especially among urban population.

In addition to the national trends in terms of calorie, protein and fat intake that are explained above, it would also be of immense interest to understand its behaviour across different States. The maps given below indicate the increase/decrease in absolute intake in calorie, protein and fat during 200405 and 2011-12 (Gol, 2007b\&Gol, 2014b). Also, whether the absolute intake is above or below national average has also been provided. The rationale being - for instance, there may not be an increase in absolute intake in some State(s), but the intake of nutrient(s) for these States may be above national average. Therefore, increase or decrease in intake has to be looked into in conjunction with the present levels of intake. Accordingly, four categories, as mentioned below, have been prepared to understand the present intake level of nutrients with respect to national average and the trend from 2004-05 to 201112 (Table 2).

Table 2: Categories Based on Levels of Intake and Its Change

\begin{tabular}{|c|c|c|}
\hline S. No. & Description & Colour Shown on Map \\
\hline 1 & $\begin{array}{l}\text { Positive change (\%) during } 04-05 \text { to } 11-12 \& \text { level of intake } \\
\text { above national average }\end{array}$ & \\
\hline 2 & $\begin{array}{l}\text { Negative change }(\%) \text { during } 04-05 \text { to } 11-12 \& \text { level of intake } \\
\text { above national average }\end{array}$ & \\
\hline 3 & $\begin{array}{l}\text { Positive change (\%) during } 04-05 \text { to } 11-12 \& \text { level of intake } \\
\text { belownational average }\end{array}$ & \\
\hline 4 & $\begin{array}{l}\text { Negative change }(\%) \text { during } 04-05 \text { to } 11-12 \& \text { level of intake } \\
\text { below national average }\end{array}$ & \\
\hline
\end{tabular}

In terms of calorie and protein intake, more States in urban areas are above the national average of intake than the States in rural areas; whereas in case of fat intake, more rural States are above the national average than urban States. Amongst all four categories, the States falling in category 4 are really a cause of concern, wherein the average intake is lower than national average and there has also been de-growth in absolute term. As shown in Figures 2, 3 and 4, there are 11 States in rural areas and 8 States in urban areas falling into category 4 in terms of calorie intake; whereas 12 States in rural and 
14 States in urban areas belong to category 4 the analysis highlights that generally, the in terms of protein intake. In terms of fat north east States depict a scenario which intake, 7 States each in rural and urban areas is not encouraging in terms of nutrient in India fall under category 4. In a nutshell, intake.

Figure 2: Per Consumer Unit Per Day - Calorie Intake

$\underline{\text { Rural }}$

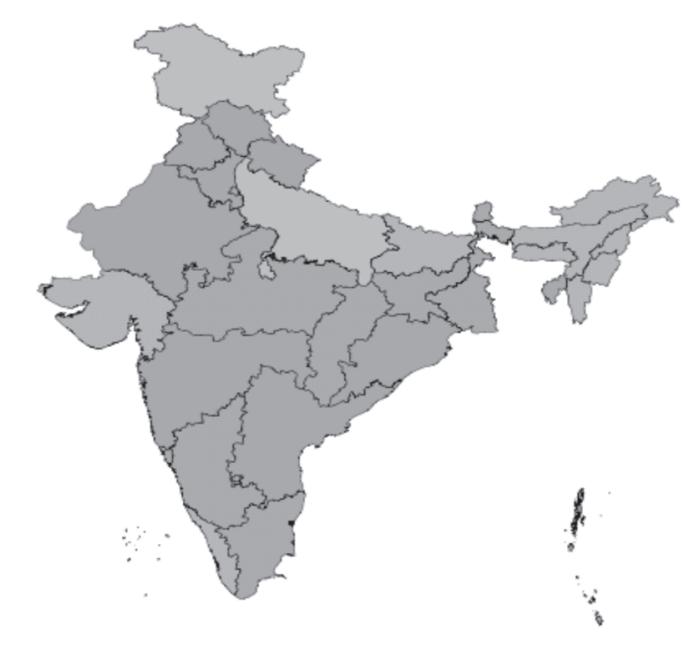

$\underline{\text { Urban }}$

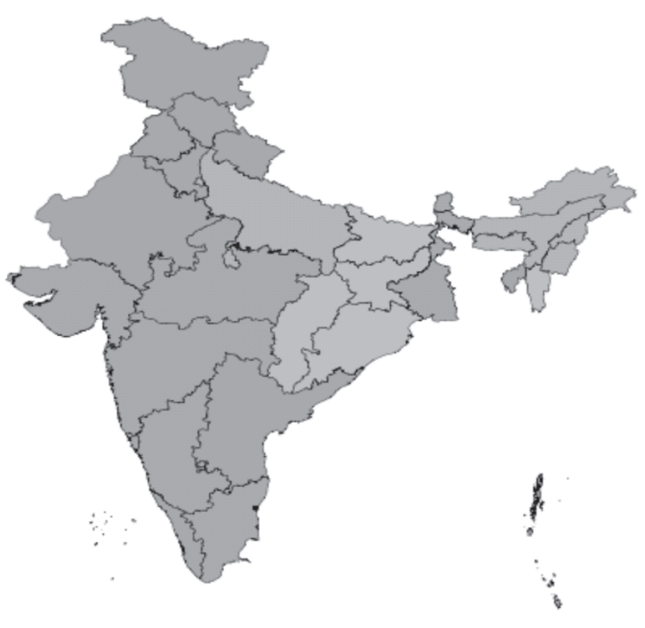

Figure 3: Per Consumer Unit Per Day - Protein Intake Rural $\underline{\text { Urban }}$
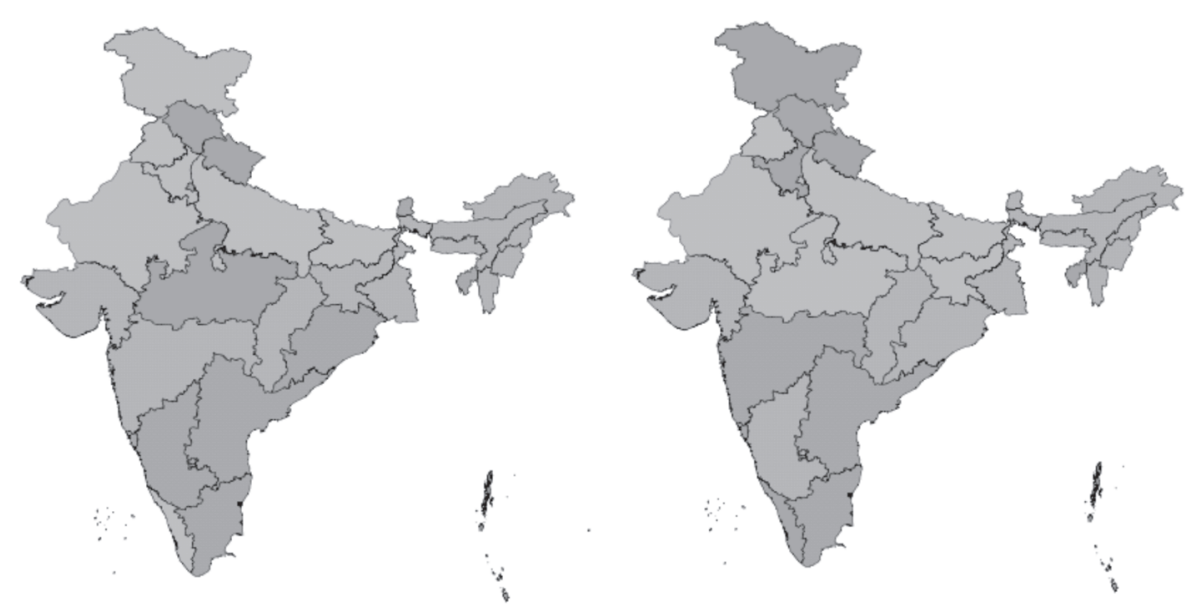

Journal of Rural Development, Vol. 36, No. 3, July-September : 2017 
Figure 4: Per Consumer Unit Per Day - Fat Intake
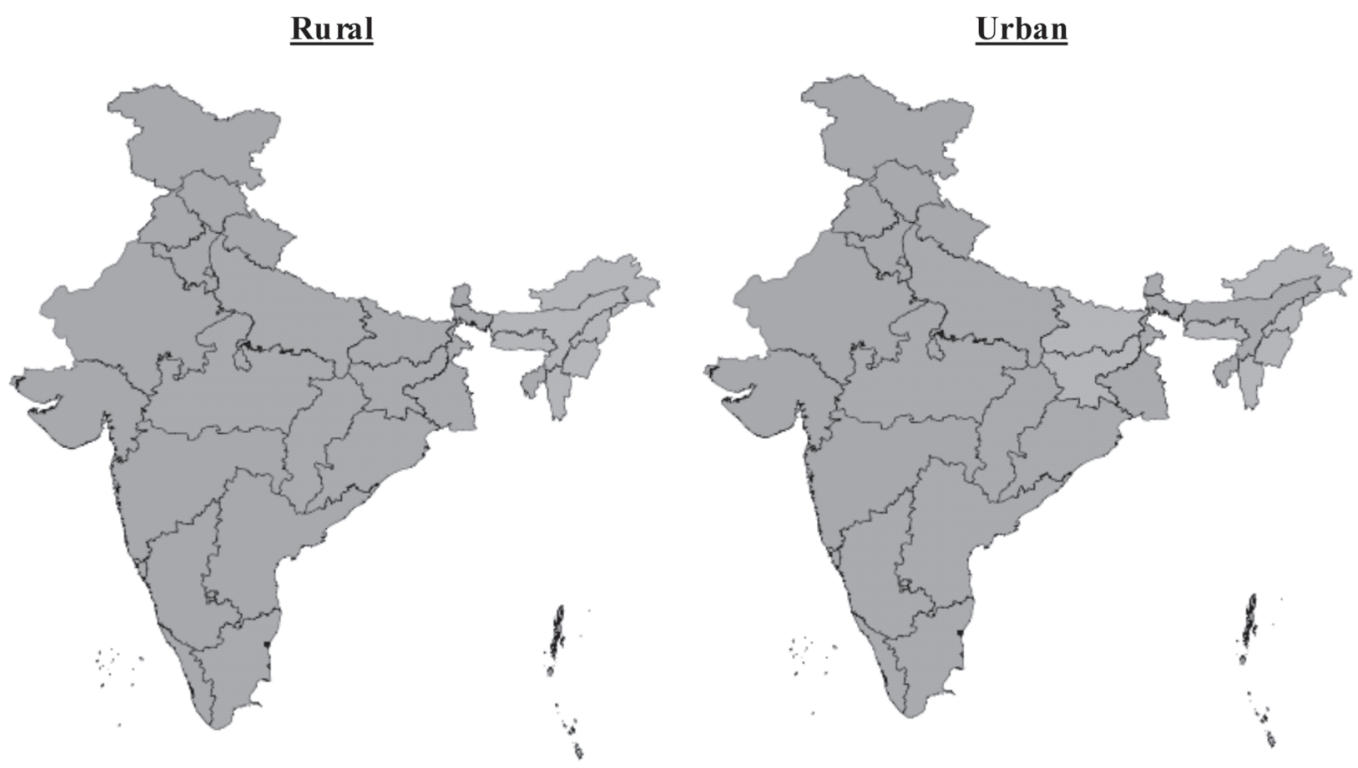

If one looks at the trend (positive or per consumer unit intake during 2004-05 and negative) singularly irrespective of considering 2011-12 (Category $2 \& 4$ clubbed and given national average in terms of calorie, protein in Figure 5). This is one area which needs and fat intake, it is the protein where maximum attention - as far as calorie and fat intakes are number of States both in rural and urban concerned. Majority of the States depicted areas exhibited declining trend in terms of positive trend, unlike protein. 
Figure 5: Distribution of States by Change in Calorie, Protein and Fat Intake (2004-05 to 2011-12)
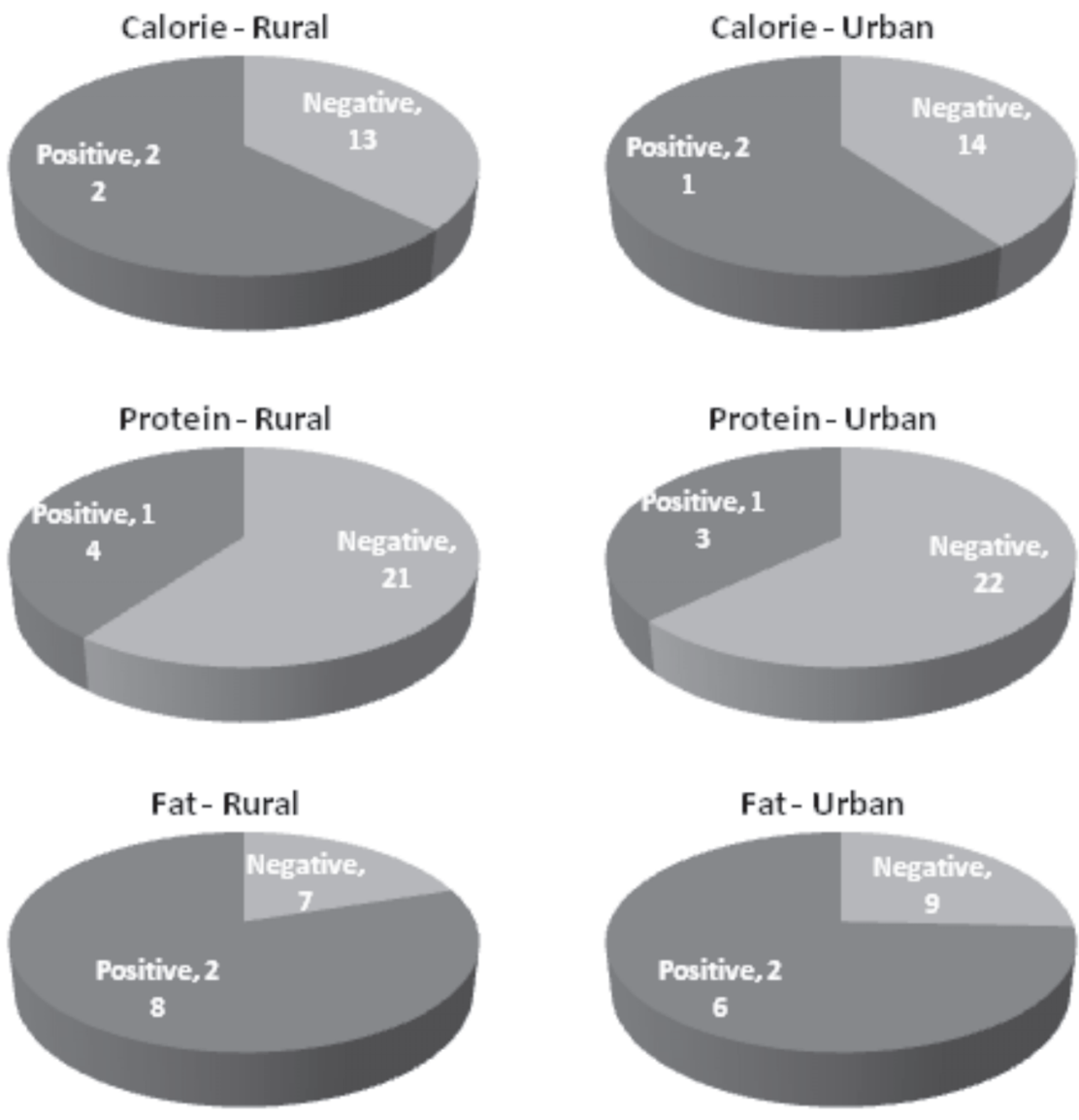

Relative Dearness of Energy and Nutrients Across Major Food Groups

There are varieties of food choices that one can make but most of the choices for lower and middle classes that form a large chunk of the population are pre-empted on the basis of the prices. Here, a comparison between the amount of energy and nutrients and their values from different food groups like cereal, pulses, milk, meat, etc., is presented below in Table 3 . 
Table 3: Relative Dearness of Energy and Nutrients Across Major Food Groups (2011-12)

\begin{tabular}{|lccccccccc|}
\hline Commodity & Unit & $\begin{array}{c}\text { Calorie } \\
\text { (Kcal) }\end{array}$ & $\begin{array}{c}\text { Protein } \\
\text { (gms) }\end{array}$ & $\begin{array}{c}\text { Fat } \\
\text { (gms) }\end{array}$ & $\begin{array}{c}\text { Value* } \\
\text { (?) }\end{array}$ & $\begin{array}{c}\text { ?/Kcal } \\
\text { of } \\
\text { energy }\end{array}$ & $\begin{array}{c}\text { ?/g } \\
\text { of } \\
\text { protein }\end{array}$ & $\begin{array}{c}\text { ?/g of } \\
\text { fat }\end{array}$ \\
\hline Cereals & $\mathrm{kg}$ & 3268 & 94 & 15 & 15 & 0.005 & 0.16 & 1.01 \\
Pulses & $\mathrm{kg}$ & 3464 & 224 & 22 & 55 & 0.016 & 0.25 & 2.50 \\
Milk \& milk products & & & & & & & & \\
Liquid milk & litre & 1000 & 40 & 70 & 26 & 0.026 & 0.65 & 0.37 \\
Milk: condensed/powder & $\mathrm{kg}$ & 4960 & 258 & 267 & 243 & 0.049 & 0.94 & 0.91 \\
Meat, fish \& eggs & & & & & & & & \\
Eggs & $\mathrm{no}$ & 100 & 8 & 8 & 4 & 0.036 & 0.44 & 0.44 \\
Goat meat/ mutton & $\mathrm{kg}$ & 1180 & 214 & 36 & 255 & 0.216 & 1.19 & 7.09 \\
Chicken & $\mathrm{kg}$ & 1090 & 259 & 6 & 117 & 0.107 & 0.45 & 19.51 \\
Fish & $\mathrm{kg}$ & 1050 & 140 & 20 & 91 & 0.087 & 0.65 & 4.57 \\
Fats \& oils & & & & & & & & \\
Ghee & $\mathrm{kg}$ & 9000 & -- & 1000 & 333 & 0.037 & -- & 0.33 \\
Butter & $\mathrm{kg}$ & 7290 & -- & 810 & 230 & 0.032 & -- & 0.28 \\
Edible oil & $\mathrm{kg}$ & 9000 & -- & 1000 & 80 & 0.009 & -- & 0.08 \\
\hline
\end{tabular}

* Based on weighted average of rural and urban expenditure on respective items. Source: Gol (2014a) \&Gol (2014b).

Cereals and pulses are relatively cheaper source of calories and proteins, while animal derived products like milk, meat and fish are on the costlier side. Nevertheless, most dieticians recommend inclusion of abundant variety in adequate quantity in the diet as each kind of food have their own importance in the well-being of the body and each food type provides nourishment in a unique combination of different nutrients.

Recommended Dietary Allowances (RDA) and Population Distribution by Calorie Intake Across Regions

The highly advanced innate cognitive ability of human beings has been gifted to control senses, but this has at least one disadvantage when it comes to diets. In other words,normally a person finds it irresistible to say no to the favourite food even when not hungry. At such instances, we tend to ignore the content and pros\& cons of such foods knowingly or unknowingly. Animals don't face such problems, they eat when they are hungry and eat only what is required. This saves them from lots of dietary complications. One needs to be disciplined and not sway to temptations for maintaining a proper and healthy diet every day.

Various institutions and dieticians have come up with recommended dietary allowances - popularly referred to as RDA. Since, the required calorie intake depends upon a multitude of factors such as genetic make-up, environment, lifestyle, ethnicity, height, weight, age, etc., it's very difficult to set a standard norm uniformly across. Nevertheless, FAO prescribes a minimum of 
$1800 \mathrm{Kcal}$ a day throughout the globe. The ICMR-NIN norm suggests a per capita per day of $2022 \mathrm{Kcal}$ for urban people and $2226 \mathrm{Kcal}$ for people belonging to rural India. Since, we are referring to consumer units throughout this paper, this RDA when converted to consumer units works out to be $2488 \mathrm{Kcal}$ in urban and $2737 \mathrm{Kcal}$ in rural regions. In nutritional intake reports of NSS, however, the distribution of population by level of calorie intake is expressed as a percentage of a level of $2700 \mathrm{Kcal}$ per consumer unit per day. Therefore, the reference calorie intakes of 2430 Kcal per consumer unit per day for urban and $2700 \mathrm{Kcal}$ per consumer unit per day for rural region have been taken for present analysis.

According to literature, the nutritional intake is categorised as deficient when the consumption of the nutrition is at least 90 per cent less than that of the RDA. There are also suggestions of the prevalence of far greater nutritional deficiency at less than 70 per cent of the consumer unit norm (Chandrasekhar and Ghosh, 2003). Nevertheless, the benchmark of 90 percent is considered for the present analysis. Based on RDA, three categories have been formed, viz., (i) less than 90 per cent of RDA, i.e., deficient intake (ii) 90-100 percent of RDA, i.e., adequate intake and (iii) in excess of 100 per cent of RDA, i.e., excess intake. These categories have been formed separately for both rural and urban areas.

As discussed earlier, whatever food is consumed, will get converted to energy which is measured in terms of calories or Kcal. This serves as a basic indicator of one's well-being although investigation of many other parameters is important to truly establish the quality of diet.

The State-wise NSS data depicting distribution of persons by calorie intake has been aggregated to regions as given below in Table 4.

Table 4: Regions of the Country

\begin{tabular}{|ll|}
\hline Region & States \\
\hline East & Bihar, Odisha, West Bengal, Chhattisgarh, J harkhand \\
North & Haryana, Punjab, Rajasthan, Uttar Pradesh, Himachal Pradesh, Jammu \& \\
& Kashmir, Uttarakhand \\
North East & Arunachal Pradesh, Assam, Manipur, Meghalaya, Mizoram, Nagaland, Sikkim, \\
& Tripura \\
South & Andhra Pradesh, Karnataka, Kerala, Tamil Nadu \\
Union & A \& N Islands, Chandigarh, D \& N Haveli, Daman \& Diu, Delhi, Lakshadweep, \\
Territories (UT) & Puducherry \\
West & Gujarat, Madhya Pradesh, Maharashtra, Goa \\
\hline
\end{tabular}

Journal of Rural Development, Vol. 36, No. 3, July-September : 2017 
The following analysis presents in population, both in rural and urban areas, interesting insights and somewhat encouraging falling well below the RDA during 2004-05 figures when analysed by regions. At the and 2011-12.

national level, there was a noticeable reduction

Table 5: Distribution of Persons by Level of Calorie Intake (In Million Numbers) Rural

\begin{tabular}{|c|c|c|c|c|c|c|}
\hline \multirow{2}{*}{ Region } & \multicolumn{3}{|c|}{ 2011-12 } & \multicolumn{3}{|c|}{$2004-05$} \\
\hline & $\begin{array}{l}\text { Deficient } \\
\text { Intake }\end{array}$ & $\begin{array}{l}\text { Adequate } \\
\text { Intake }\end{array}$ & $\begin{array}{l}\text { Excess } \\
\text { Intake }\end{array}$ & $\begin{array}{l}\text { Deficient } \\
\text { Intake }\end{array}$ & $\begin{array}{l}\text { Adequate } \\
\text { Intake }\end{array}$ & $\begin{array}{l}\text { Excess } \\
\text { Intake }\end{array}$ \\
\hline All India & $335.5(42)$ & $154.3(20)$ & 302.3 (38) & 360.3 (49) & 125.5 (17) & $247.3(34)$ \\
\hline East & $96.0 \quad(44)$ & $43.7 \quad(20)$ & 80.1 (36) & $94.3(48)$ & 35.0 (18) & 67.8 (34) \\
\hline North & $85.5 \quad$ (35) & $48.8 \quad(20)$ & 111.4 (45) & 84.7 (38) & 40.2 (18) & 99.1 (44) \\
\hline North E & $18.5 \quad(54)$ & $7.3 \quad(21)$ & $8.6 \quad(2$ & 15.3 & $6.8 \quad(22)$ & $9.0 \quad(29)$ \\
\hline South & $70.6 \quad(47)$ & $27.7 \quad(18)$ & 52.3 (35) & $85.3(58)$ & 22.7 (15) & 38.4 (26) \\
\hline UT & $0.8 \quad(41)$ & $0.4 \quad(20)$ & $0.8 \quad$ (39) & 1.0 & $0.2 \quad(12)$ & $0.5 \quad(29)$ \\
\hline West & $64.2 \quad(46)$ & 26.3 (19) & 49.2 (35) & $79.2(60)$ & 20.6 (15) & 32.9 (25) \\
\hline
\end{tabular}

\begin{tabular}{|c|c|c|c|c|c|c|c|c|c|c|}
\hline \multirow{3}{*}{ Region } & \multirow{2}{*}{\multicolumn{4}{|c|}{ 2011- 12}} & \multicolumn{6}{|c|}{ 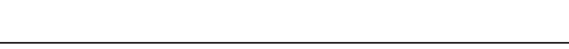 } \\
\hline & & & & & \multicolumn{6}{|c|}{ 2004-05 } \\
\hline & $\begin{array}{l}\text { Deficient } \\
\text { Intake }\end{array}$ & $\begin{array}{l}\text { Ade } \\
\text { In }\end{array}$ & $\begin{array}{l}\text { luate } \\
\text { ake }\end{array}$ & $\begin{array}{l}\text { Excess } \\
\text { Intake }\end{array}$ & $\begin{array}{r}\text { Def } \\
\text { In }\end{array}$ & $\begin{array}{l}\text { cient } \\
\text { ake }\end{array}$ & $\begin{array}{l}\text { Ade } \\
\text { In }\end{array}$ & $\begin{array}{l}\text { quate } \\
\text { ake }\end{array}$ & $\begin{array}{l}\text { Exce } \\
\text { Inta }\end{array}$ & \\
\hline All India & 91.0 (29) & 61.0 & (19) & $165.0(52)$ & 83.0 & (33) & 50.0 & (20) & 115.0 & (47) \\
\hline East & 13.0 & 9.0 & (19) & 26.0 & 11.0 & (28) & 8.0 & (20) & 20.0 & (52) \\
\hline North & 21.0 (28) & 13.0 & (17) & 42.0 (55) & 17.0 & (27) & 12.0 & (20) & 33.0 & (53) \\
\hline North East & $2.0 \quad(29)$ & 1.0 & (21) & $3.0 \quad(50)$ & 1.0 & (23) & 1.0 & (19) & 2.0 & (58) \\
\hline South & 25.0 & 17.0 & (20) & $43.0(50)$ & 23.0 & (37) & 12.0 & (19) & 27.0 & (44) \\
\hline UT & 5.0 (33) & 2.0 & (18) & 7.0 (49) & 4.0 & (29) & 2.0 & (18) & 7.0 & (53) \\
\hline West & 25.0 (28) & 18.0 & (20) & $45.0(52)$ & 27.0 & (40) & 15.0 & (22) & 26.0 & (38) \\
\hline
\end{tabular}

Source: Derived from Gol (2007b) \& Gol (2014b).

Note: Figures in parentheses indicate percentages.

At all India level, 42 per cent of the rural population remains undernourished in rural areas, whereas it is at 29 per cent in urban areas. Across the regions, same or higher proportions of rural mass remains undernourished, barring northern region and Union Territories. In urban areas, the proportion of people in the undernourished category was marginally higher than national average in southern region and Union Territories(Table 5).
It is equally interesting to look at the reduction in percentage population belonging to "deficient intake" category across the regions during 2004-05 and 2011-12. There was a drop of 6.8 percentage points in undernourished rural population at the national level. However, the same were quite impressive in Union Territories (17.8 per cent), western (13.7 per cent) and southern (11.4 per cent) regions. Similarly, the urban population 
belonging to deficient intake category has reduced by 4.8 percentage points at the aggregate level, the western (11.7 per cent) and southern (7.8 percent) were reportedly better-off across the regions. The eastern region has shown marginal improvement in both rural and urban (4 and 1 percent, respectively) regions. On the other hand, the north east region reported increase in proportion of population having deficient energy intake from 2004-05 to 2011-12.

These single digit percentage changes translate into overwhelming numbers, i.e., while almost 335 million people in rural areas in 2011-12 fall into undernourished category, as compared to 360 million in 2004-05 meaning 25 million in 7 years have been uplifted from undernourishment to adequate levels of intake. In urban areas, the same numbers stood at 91 million in 2011-12 and 83 million in 2004-05, a reduction by 8 million.

\section{Propensity to Consume}

An interesting perspective can be drawn when the propensity towards consumption of calories, proteins and fast visà-vis expenditure of food are analysed. The elasticity coefficients across the regions have been estimated to examine the changes in the inclination of the consumers over different nutrients with rise in food expenditure (Gol, 2007a, 2007b, 2014a and 2014b). The MPCE data by fractile classes have been used to carry out the present analysis.
With rise in consumer expenditure, there has been a higher propensity to spend on non-food items. According to Consumer Expenditure Survey reports of different rounds, the shares of food expenditure in total spending have been estimated at 59.4, 55.0 and 48.6 percent in 1999-2000, 2004-05 and 2011-12, respectively, in rural areas. These proportions stood at 48.1, 42.5 and 38.5 per cent in urban areas for same reference years. Therefore, with increase in level of income and improvement in lifestyles, there has been a diversification in the consumption basket from food-based items to non-food items.This phenomenon logically leads to a situation where increase in expenditure does not proportionally lead to rise in expenditure on food items.

The elasticity coefficients have been less than one in case of calorie, protein and fat (Table 6). A similar trend holds true across both the periods i.e., 2004-05 and 2011-12, albeit with varying magnitude across the regions. It may be seen that from 2004-05 to 2011-12, there is a uniform fall in elasticity coefficients across all the nutrients. The results of elasticity coefficients also indicate that the rise in food expenditure increases the propensity to consume more of fat in comparison to calorie or protein. This may be partly attributed to the increasing trend of consuming processed foods, fast foods and packaged instant/ready-made food products; which are generally high in fat content However, an in-depth detailing is required to 
substantiate this argument. The drop in elasticity coefficients was relatively pronounced in rural areas in comparison to urban areas and the same held true across the regions too, however, the region-wise magnitude of drop in the coefficients varied.

\section{Table 6: Elasticity Coefficients}

a) Calorie \& Food

\begin{tabular}{|lcccc|}
\hline Region & \multicolumn{2}{c}{ Rural } & \multicolumn{2}{c|}{ Urban } \\
\hline All India & $2011-12$ & $2004-05$ & $2011-12$ & $2004-05$ \\
East & $0.272^{* *}$ & $0.659^{* *}$ & $0.278^{* *}$ & $0.577^{* *}$ \\
North & $0.266^{* *}$ & $0.548^{* *}$ & $0.338^{* *}$ & $0.481^{* *}$ \\
North East & $0.239^{* *}$ & $0.521^{* *}$ & $0.410^{* *}$ & $0.487^{* *}$ \\
South & $0.176^{* *}$ & $0.534^{* *}$ & $0.229^{* *}$ & $0.865^{* *}$ \\
UT & $0.373^{* *}$ & $0.561^{* *}$ & $0.292^{* *}$ & $0.466^{* *}$ \\
West & $0.379^{* *}$ & $0.570^{* *}$ & $0.289^{* *}$ & $0.518^{* *}$ \\
\hline
\end{tabular}

** significant at 1 per cent

b) Protein \& Food

\begin{tabular}{|lcccc|}
\hline Region & \multicolumn{2}{c}{ Rural } & \multicolumn{2}{c|}{ Urban } \\
\hline & $2011-12$ & $2004-05$ & $2011-12$ & $2004-05$ \\
\hline All India & $0.324^{* *}$ & $0.700^{* *}$ & $0.310^{* *}$ & $0.624^{* *}$ \\
East & $0.339^{* *}$ & $0.613^{* *}$ & $0.396^{* *}$ & $0.533^{* *}$ \\
North & $0.270^{* *}$ & $1.004^{* *}$ & $0.392^{* *}$ & $0.435^{* *}$ \\
North East & $0.222^{* *}$ & $0.684^{* *}$ & $0.260^{* *}$ & $1.012^{* *}$ \\
South & $0.404^{* *}$ & $0.614^{* *}$ & $0.362^{* *}$ & $0.521^{* *}$ \\
UT & $0.459^{* *}$ & $0.689^{* *}$ & $0.299^{* *}$ & $0.563^{* *}$ \\
West & $0.347^{* *}$ & $0.365^{* *}$ & $0.209^{* *}$ & $0.395^{* *}$ \\
\hline
\end{tabular}

** Significant at 1 per cent

c) Fat \& Food

\begin{tabular}{|lcccc|}
\hline Region & \multicolumn{2}{c}{ Rural } & \multicolumn{2}{c|}{ Urban } \\
\hline & $2011-12$ & $2004-05$ & $2011-12$ & $2004-05$ \\
\hline All India & $0.537^{* *}$ & $1.078^{* *}$ & $0.531^{* *}$ & $0.977^{* *}$ \\
East & $0.640^{* *}$ & $1.144^{* *}$ & $0.824^{* *}$ & $1.201^{* *}$ \\
North & $0.472^{* *}$ & $1.352^{* *}$ & $0.754^{* *}$ & $0.938^{* *}$ \\
North East & $0.519^{* *}$ & $1.212^{* *}$ & $0.482^{* *}$ & $1.170^{* *}$ \\
South & $0.501^{* *}$ & $0.898^{* *}$ & $0.510^{* *}$ & $0.859^{* *}$ \\
UT & $0.618^{* *}$ & $0.981^{* *}$ & $0.407^{* *}$ & $0.780^{* *}$ \\
West & $0.500^{* *}$ & $0.851^{* *}$ & $0.260^{*}$ & $0.809^{* *}$ \\
\hline
\end{tabular}

** Significant at 1 per cent, * Significant at 5 per cent 


\section{Conclusion}

There is a great Indian paradox that has been baffling the researchers and policymakers for quite some time now. The decline in calorie intake levels over the years is hard to explain when most factors affecting the intake levels have shown a positive trend. The rising income, better productivity, availability and accessibility of foodgrains and government schemes and policies make it difficult to discern this oxymoron behaviour.There can be a multitude of views for this behaviour but it is difficult to pin point to a single reason which may possibly explain the observed phenomenon. Most probably, it is due to higher preference for spending on consumer durables and non-food items. It means when a basic level of food requirement is met, people attach less importance to food and start spending more towards non-food items. Another major reason for it could be lack of awareness about balanced nutrition among majority of people. Nonetheless, people in urban centres have started becoming conscious about importance of proper nutrition. It may take several years before it spreads evenly throughout the urban India and then finally trickle down to rural areas; it is certainly easier said than done and it would be a herculean task in itself requiring active participation of people, governments, NGOs, healthcare providers and other stakeholders.

While the calorie and protein intake both in rural and urban areas have been waning down with varying degree over the years, the fat intake on the contrary has been rising. Numerically, a decline of about 1-4 per cent in calorie and 3-7 per cent in protein intake has been registered during last 18 years ending 2011-12, whereas the fat intake during the same period has shown substantial increase of 25-30 per cent in rural and urban areas of the country. This may also reflect the fad of increase in consumption of fatty processed foods and increasing popularity of such food among masses, especially among the youth.These trends may take Indian population further away from the quintessential diet that is desirable for a healthy living. This may also be the underlying reason behind the ever-increasing instances of lifestyle related diseases at relatively younger age day by day.

At all India level, about 42 and 29 per cent of the rural and urban population has deficient intake of calories per day. In 2011-12, there has been a drop of about 7 per cent in undernourished population in rural areas, while the same stood at about 5 per cent in urban areas, as compared to 2004-05. If one translates these percentages into numbers, about 25 million people in rural India and about 8 million in urban India have come out of malnutrition category. Across the regions, the improvement in nutritional intake was quite impressive in western and southern regions of the country during 2004-05 and 2011-12.

Since India is a country full of diversity, the intake level of different foods also varies greatly. The analysis of the intake level data of various regions namely, northern, eastern, western, southern, north eastern and UTs elicit 
interesting observations. In general, the north eastern region of the country seems lagging in having proper diet. Now, it will be interesting to study whether this is due to lower income levels of people or the food habit per se. For instance, in urban Gujarat, where people are comparatively better off as compared to most other regions of the country, the calorie and fat intake is found to have more than national average, but with inadequate proteins in their diets.

Computation of propensity to consume different nutrients with rise in consumer expenditure revealed that people are most affectionate and liberal towards fat while protein and calorie intake are kept on the back burner. This behaviour again partially reflects the unawareness among the society at large. The coefficient of elasticity shows that energy and nutrient intake do not increase in tandem with rise in food expenditure but in terms of fat intake, the coefficient was relatively high.

Therefore, making proper nutrition available and affordable to masses remains one of the leading challenges that the country faces today. With the ever-rising incidence of lifestyle diseases, more so in the recent years, spreading awareness through active participation of all the stakeholders has to be given paramount importance. Inculcating appropriate food habits right from childhood and disseminating information through schools would be a welcome step. 


\section{References}

1. Ali, J (2007), "Structural Changes in Food Consumption and Nutritional Intake from Livestock Products in India," South Asia Research, Vol. 27, Issue 2, pp. 137-15.

2. Atibudhi, H N (2006), "A Comparative Analysis of Food Consumption and Monthly Per Capita Expenditure of Orissa vis-a-vis All India Level,"Indian Journal of Agricultural Economics, Vol. 61, Issue 3, July-September.

3. Basu, Depankar and Basole,Amit (2012), "The Calorie Consumption Puzzle in India: An Empirical Investigation," Economics Department Working Paper Series, University of Massachusetts, Paper 147.

4. Chandrasekhar, CP and Ghosh, Jayati (2003), "The Calorie Consumption Puzzle”, Economic Research Foundation, Macroscan, February.

5. Deaton A and Dreze,J (2009), “Nutrition in India: Facts and Interpretations, Economic and Political Weekly, 44(7), pp. 42-65, February.

6. Giri, A K (2006), "Cereal Consumption Over Time in the Country and Across the States,"Indian Journal of Agricultural Economics, Vol. 61, Issue 3.

7. Golait, R and Pradhan, N C (2006), "Changing Food Consumption Pattern in Rural India: Implication on Food and Nutrition Security, Indian Journal of Agricultural Economics, Vol. 61, Issue 3, July-September.

8. Government of India (2007a), "Level and Pattern of Consumer Expenditure- 2004-05," 61st Round, Report No. 508, National Sample Survey Organisation, Ministry of Statistics and Programme Implementation, New Delhi, July, 2004 - June, 2005.

9. National Sample Survey Organisation, Ministry of Statistics and Programme Implementation, New Delhi, July, 2004 - June, 2005.

10. - --------- (2014a), "Level and Pattern of Consumer Expenditure, 2011-12, 68th Round, Report No. 555, National Sample Survey Organisation, Ministry of Statistics and Programme Implementation, New Delhi, July, 2011 - June, 2012.

11. - ------ (2014b), "Nutritional Intake in India, 2011-12,"68th Round, Report No. 560, National Sample Survey Organisation, Ministry of Statistics and Programme Implementation, New Delhi, July, 2011 - June, 2012.

12. International Conference on Nutrition (1992), "Human Nutrition in the Developing World," FAO Corporate Document Repository,http://www.fao.org/docrep/w0073e/w0073e03.htm.

13. Li, Nicholas and Eli Shari (2010), "In Search of India's Missing Calories: Energy Requirements http://emlab.berkeley.edu/ webfac/emiguel/e271_f10/Li.pdf 
14. Mehta, J and Venkatraman, S (2000), "Poverty Statistics: Bermicide's Feast, Economic and Political Weekly, 35(27):2377-2379+2381-2382, July, 2000.

15. Mittal, S (2007), "What Affects Changes in Cereal Consumption?, Economic and Political Weekly, 42(5), pp. 444-447, February.

16. Nasurudeen, P; Kuruvila, A; Sendhil, R and Chandresekar, V (2006), "The Dynamics and Inequality of Nutrient Consumption in India,"Indian Journal of Agriculture Economics, Vol. 61, Issue 3, pp. 362-373.

17. National Institute of Nutrition (2011), "Dietary Guidelines for Indians- A Manual,"Indian Council of Medical Research, Hyderabad (India).

18. Patnaik, U (2004), "The Republic of Hunger, Social Scientist, 32(9/10):9-35, SeptemberOctober.

19. ------ (2007), “Neoliberalism and Rural Poverty in India,” Economic and Political Weekly, 42 (30):3132-3150, July.

20. ------- (2010a), "A Critical Look at Some Propositions on Consumption and Poverty, Economic and Political Weekly, 45(6):74-80, February.

21. ------ (2010b), "On Some Fatal Fallacies,"Economic and Political Weekly, 45(47):81-87, February.

22. Radhakrishna, R (2006),"Food Consumption and Nutritional Status in India: Emerging Trends and Perspectives," Working Paper, November, Indira Gandhi Institute of Development Research, Mumbai, November.

23. Ramachandran, Prema (2008), "Changing Food Consumption Pattern in India," Bulletin of the Nutrition Foundation of India, Vol. 29, No. 2, April.

24. Rao,Ch H (2000), "What Affects Changes in Cereal Consumption?, Economic and Political Weekly, 35(4), pp. 201-206, January.

25. Ray, R (2007), "Changes in Food Consumption and Implications for Food Security and Undernourishment: India in the 1990s," Development and Change, 38 (2), pp.321-343.

26. Ray, R and Lancaster, G (2005), "On Setting the Poverty Line Based on Estimated Nutrient Prices: Condition of Socially Disadvantaged Groups During the Reform Period, Economic and Political Weekly, 40, pp. 46-56.

27. Shariff A, Mallick A C (1999),"Dynamics of Food Intake and Nutrition by Expenditure Class in India,"Economic and Political Weekly, Vol. 34, Issue 27, pp. 1790-1800.

28. Shimokawa, Satoru (2012), "When Does Dietary Knowledge Matter to Obesity and Overweight Prevention?, Food Policy, Volume 38, pp. 35-46, November. 
29. Singh, RK; Vishwakarma, A and Singh P K (2006), “Food Security and Policy Perspective in India, Indian Journal of Agricultural Economics, Vol. 61, Issue 3.

30. Viswanathan, B (2001), “Structural Breaks in Consumption Patterns: India 1952-1991, Applied Economics, Vol. 33, Issue 9; pp. 1187-1200.

31. World Bank (2011), "An Urgent Call for Action: Undernourished Children of South Asia," $<$ <ttp://www.worldbank.org/poverty. 